\title{
An Analysis of the Task-Based Syllabus
}

\author{
Simon James Nicholson \\ Assistant Professor, Foreign Languages Education Center \\ Hankuk University of Foreign Studies
}

89 Wangsan-ri, Mohyeon-myeon, Choin-gu, Yongin-si, Gyeonggi-do, South Korea

Tel: 82-10-8974-1948Ｅ-mail: simonjamesnicholson@gmail.com

Received: March 9, 2014 Accepted: March 23, 2014 Published: March 23, 2014

doi:10.5296/ijele.v2i1.5348 URL: http://dx.doi.org/10.5296/ijele.v2i1.5348

\begin{abstract}
The task-based syllabus is the best model for providing a flexible framework for the promotion of L2 and the communicative use of language while recognizing the individuality of the learner. It provides opportunities for the real use of language while tasks relevant to learners needs and interests intrinsically motivate learners. This paper examines the theories that have influenced the task-based syllabus and looks at both its strength and weaknesses, identifying language learning contexts where it is best suited while showing that it is in-line with SLA research findings that propose that language learners do not acquire language one form at a time but rather through more complicated cognitive processes.
\end{abstract}

Keywords: Task-Based Syllabus, Tasks, Comprehensible Input, Negotiation of Meaning, Motivation, Learner Individuality, Communicative Competence, Fossilization 


\section{Introduction}

As many teachers can attest to, what is learnt in the way of formal grammar teaching is often not what is used by language learners in communication. In addition and running parallel to this, many language students, especially those in L2 environments, suffer from the lack of use of English outside the classroom as there are not enough opportunities presented to students for the authentic, meaningful use of the English language. Where this exists, there is a need to create such an atmosphere within the classroom for the use of language, a sentiment echoed by Ellis (2009). A task-based syllabus proposes to address both these problems and do so in a way that puts the learner at the center of the learner process.

This paper will first provide a definition for the task-based syllabus (TBS). The author will then proceed to examine the theories of language and learning that have influenced it. Following this, the writer will critically identify strengths and weaknesses of TBS before showing the situations I believe that it is best suited to and finally arguing that it is the best model for providing a flexible framework for the promotion of L2 learning and the communicative use of language while recognizing the individuality of the learner.

\section{What is a Task-Based Syllabus?}

In this paper, I will use Willis's 'strong version' (Willis 1996b) of task-based language teaching (TBLT) where tasks are taken to be "the central component of syllabus design" (Butler, 2011: 38). This is in contrast to Ellis's weaker version of TBLT (Ellis 2003) where the task is used "for communicative practice in conjunction with a grammar-or function-based syllabus" (Butler, 2011: 38). I believe the former is in line with definitions of TBS (see below), whereas the later refers to task-supported teaching. With this in mind, the paper will first provide a definition of 'TBS' and 'task' before examining the theories that have influenced this syllabus type in Section 3.

\subsection{Task-Based Syllabus}

A syllabus is a narrower aspect of the broader curriculum and is "a specification of the content of instruction and lists what will be taught and tested" (Richards, 2001:2). Wilkins (1981) states that the contents of a syllabus "have been submitted to some degree of structuring or ordering with the aim of making teaching and learning a more effective process" while its function is "to specify what is to be taught and in what order" (Prabhu, 1984).

Unlike the structural syllabus, where the content and units are arranged around linguistic and grammatical knowledge to be learned, TBS uses tasks as the units by which the syllabus is organized, or rather as Van den Branden asserts, they (TBS) "do not chop up language into small pieces, but take holistic, functional and communicative 'tasks', rather than any specific linguistic item, as the basic unit for the design of educational activity" (2006: 5).

TBS is therefore not concerned with what is to be learnt but with how the acquisition or learning of content is to take place thus making it a procedural syllabus by definition. TBS can further be classified as being both analytic and Type B in nature: analytic in that 
task-based syllabuses rely on learners' analytic capabilities (Wilkins 1976: 14; cited in Long \& Crookes 1992: 29) and Type B in that "they involve no artificial preselection or arrangement of items" (Long \& Crookes 1992: 14).

\subsection{Tasks}

Though various definitions of task exist within the literature, in the field of syllabus design tasks are generally classified as being either pedagogical tasks or real-world tasks. Richards (2001: 162) describes pedagogical tasks as those that are "based on SLA theory and are designed to trigger second language learning processes and strategies". He goes on to list jigsaw tasks, information gap tasks, problem solving tasks, decision making tasks and opinion exchange tasks as examples of pedagogical tasks (Richards 2001: 162).

Real world tasks, on the other hand, "are designed to practice or rehearse those activities that are found to be important in a needs analysis and that turn out to be important and useful in the real world" (Richards 2001: 162). A role-play in which the learner is called upon to call the front desk of a hotel and complain about the air conditioning would be a task of this kind, and the successful outcome will be a correctly adjusted air conditioning system rather than the production of a piece of language.

The purpose of tasks and their usefulness within syllabus design stems from their "resemblance to real-life language use" which has meaning as its primary focus (Skehan 1996: 20). By emphasizing meaning and communication over language forms and structures, "tasks are believed to promote processes of negotiation, modification, rephrasing, and experimentation that are at the heart of second language learning" (Richards \& Rodgers 2001: 228).

\section{Influential Theories}

The following section examines theories of language and learning that the author believes have influenced TBS.

\subsection{Theories of Language: The Necessity of Meaning}

In the 1970s, the way in which researchers and educators viewed language underwent a drastic 'reconceptualization' in which language was seen as a system for expressing meanings as opposed to a system of abstract syntactic rules (Nunan 1999: 9). This 'reconceptualization' is the theory of language that has most influenced the task-based syllabus. As per this theory, language learning is not an additive process of one grammar point at a time but rather that language is a communicative necessity to express meaning. This belief has clearly influenced TBS and task-based teaching as "a task based approach to learning and teaching takes meaning as it's starting point” (Willis \& Willis 2007: 177).

\subsection{Theories of Learning: Krashen's Comprehensible Input}

Krashen's theory of Comprehensible Input holds that "opportunities for second language acquisition are maximized when learners are exposed to language which is just a little beyond their current level of competence" (Krashen 1981,1982; cited in Nunan 1991:289). This puts 
a considerable amount of importance on the input of language in L2 acquisition as it is this input that drives the learners cognitive processes to understand what is being said and it is this cognitive process that drives acquisition. Krashen's Comprehensible Input has influenced TBS in that, in contrast to the stilted, impoverished and unnatural language associated with more structural or form driven syllabuses, tasks offer learners language that is both high quality and 'tuned', that is varied in form and at the edge of their comprehension (Skehan 1996: 19). It is believed that this input promotes incidental learning of "tacit or implicit knowledge" (Robinson 2011: 10) through the working out of meaning content of the input (Krashen 1982; cited in Robinson 2011: 10). The influence this theory has had on TBS is evident in its use of authentic materials in the classroom as a source of rich and varied comprehensible input.

\subsection{Theories of Learning: Negotiation of Meaning}

Though input is clearly seen as an important part to L2 acquisition, researchers (Long 1985, 1996; Gass 1997; Pica 1994, 1996) argue that input by itself is not sufficient. In order for acquisition to occur, learners must also, in addition to being exposed to input, be afforded opportunities for interaction as it is during this interaction where learners can look to negotiate meaning.

The negotiation of meaning occurs during interaction when students encounter difficulties while completing tasks. These difficulties during interaction allow for "personalised, well-timed feedback for areas of interlanguage which are problematic" (Pica 1994; cited in Skehan 2003: 2). These responses, or feedback, are given at the precise moment when the learner is thought to be the most receptive, thereby assisting the learner to move the interaction forward through the language and towards task completion.

According to this theory, interaction plays a pivotal role in L2 acquisition and the task-based syllabus has accounted for this. With tasks as the central unit of organization, plentiful opportunities exist for interaction to take place and for learners to negotiate meaning while completing each task.

\section{Strengths}

After examining the theories that have influenced TBS, this section will address what the author believes are strengths of TBS.

\subsection{In-line with SLA research}

A strength of the task-based syllabus is that it is in-line with SLA research findings that propose that language learners do not acquire language one form at a time as is representative of Type A, synthetic syllabus types, but rather through more complicated cognitive processes (Richards \& Rodgers 2001: 223). As Van den Branden states, "research shows that people do not learn isolated items in L2 ...in an additive, linear fashion, but rather as parts of complex mappings of form function relationships" (2006: 5). Thus the language learning process is comprised of far more complex cognitive processes than is reflected by formal grammar focused syllabuses. 
The task-based syllabus more directly echoes the findings of SLA research in that it focuses on meaning and learning through doing rather than on language display. As Skehan states "it is by primarily engaging in meaning that the learner's system is encouraged to develop" (Skehan 1996: 20). Furthermore, task work provides a better context for the activation of learning processes and ultimately of language learning to take place (Richards \& Rodgers 2001: 223). Therefore, a task-based syllabus maximizes the opportunities for learning to occur.

Additionally, Jane Willis (1996a: 59-60) has identified four key classroom conditions to be met in order for language learning to effectively transpire. They are the following:

- Exposure to a rich but comprehensible input of real language, i.e. the kind of language that learners will be needing or wishing to understand and use themselves.

- Opportunities for real use of language - chances for learners to experiment and test hypothesis, to mean what they say and express what they mean in a variety of circumstances.

- Motivation to listen and read, i.e. to process the exposure for meaning; and also to use the language, to speak and write.

- Focus on language - in order to prevent fossilization, and to challenge learners to strive for individual improvement, they need chances to reflect on language and to try to systematize what they know.

TBS meets these four key conditions. The use of authentic materials provides rich and varied input. The tasks themselves provide opportunities for the real use of language and to convey meaning while language use and tasks relevant to learners needs and interests intrinsically motivate learners. Task types, variables and conditions together with negotiation of meaning result in a framework for the focus on form.

\subsection{Motivating}

As many teachers can attest to, a motivated learner is a good learner. However, in many EFL learning contexts, learners do not feel motivated to learn the L2. As Willis \& Willis note:

English had become very unpopular, partly because students had no immediate need for it outside the class. They were not motivated by a grammar-based approach because it didn't convince them they could do anything with the language they were learning. (Willis \& Willis 2007: 182)

Tasks can provide both the immediate need of and opportunities for language use missing in many EFL classrooms. Additionally, Richards (2001) holds that tasks motivate learners by providing exposure to authentic language and cultural information while Willis (1996b: 14) believes that "teachers can select topics and activities that serve to motivate (them) in the short term".

As a teacher in the field of English as a foreign language, I have found that making tasks particularly relevant and interesting to groups of leaners serves to stimulate motivation and 
interest, thus reinforcing Ellis's (2009) claim that tasks can be intrinsically motivating. Furthermore, I have found that tasks assist in increasing student motivation by the nature of their goal-oriented outcome. Through task completion, students feel a sense of accomplishment and purpose to language learning as they successfully use the L2 to achieve classroom objectives, which aids in increasing levels of motivation for the following activity.

\subsection{Needs Based}

A further strength of the TBS is that what happens in class is relevant to students' needs. TBS uses needs analysis as a point of departure and this ensures that what is covered in the classroom is more likely to be relevant to the needs and specific interests of learners. Long (1985; cited in Bruton 2002: 284) points out that “target tasks based on students' needs are converted into task types. These are then converted into pedagogic tasks, which become the common core of the syllabus for all students". This addresses the classroom reality that "there is no one size fits all' solution to language instruction. Furthermore, using needs based analysis ensures that real language needs are being met in the classroom through appropriately tailored materials.

\subsection{Learner Driven}

As needs analysis (see 4.3) demonstrates, learners are at the center of the task-based syllabus. This is further emphasized through TBS's promotion of learner autonomy through a focus on form and the learner decisions this allows for. The importance of tasks is that they emphasize the meaningful exchange of language with a focus on form, which is initiated and controlled by the learner. This promotes autonomy as, "it is the individual learner who decide[s] what language items to focus on, when and why" (Willis: 2007: 2). This puts the student at the center of the learning process, which encourages the learner to become not only an independent learner but also one who learns for him or herself (J. Willis 1996b: 68; D. Willis 1996a: 76). In other words, TBS is a means not only to language acquisition but also to greater goals of long term learning processes.

\section{Weakness}

This section of the paper will examine weaknesses of the task-based syllabus. The author proposes that these weaknesses can be divided into two categories: those that are at the level of design and those that are at the level of implementation.

\subsection{Design: Selection of Tasks in General English Courses}

Long and Crookes (1992: 46) state, "Given adequate needs analysis, selection of tasks is relatively straightforward". However, in many language teaching contexts, this seemingly simple task is much more difficult to accomplish. In most EFL classrooms, English is taught for general purposes as a mandatory part of a greater institutional curriculum. The varied levels and identifiable needs of students in these situations would render it extremely difficult to arrive at a practical needs analysis that would allow for the straightforward selection of tasks for syllabus design (Sheen 1994: 144). Moreover, student needs in these learning 
contexts will be largely determined by examination content, which is heavily based on structural knowledge of the language. In addition, as Sheen points out:

[I]t would be extremely difficult to define the tasks that will be general to all students after they leave school, particularly as many will have no immediate need to use that language they have spent the previous years learning. (1994: 144)

Therefore, though needs analysis would certainly prove a beneficial and productive means of determining task selection in classroom situations in which learners have similar specific and immediate needs, in many language-learning contexts this is not the case. The result is an absence of needs identification and a rationale for the content of the syllabus (Long \& Crookes 1992: 37).

\subsection{Design: Grading and Sequencing of Tasks}

A further weakness of TBS is that of grading and sequencing tasks. As with any syllabus design, units of work should be progressively more challenging as the course advances. This means that syllabus designers must determine the difficulty of individual tasks prior to putting them into a set sequence in the syllabus. However, there are a number of variables that determine the difficulty of tasks, which need to be considered. Ellis believes that there are three different factors that influence task difficulty or, in other words, the "ease with which learners are able to perform different tasks" (Ellis 2003: 67). They are as follows:

- Inherent characteristics of the task itself (nature of input, task conditions, processing operations involved in completing the tasks and the outcome that is required).

- Learners as individuals (how easy or difficult a particular task is for different participants: intelligence, language aptitude, learning style, memory capacity and motivation).

- Methodological procedures used to teach a task (use of pre-task activity and providing planning time).

Clearly, in TBS design, "the difficulty resides in the task itself" (Long \& Crookes 1992: 45) and in determining not only the manner in which tasks relate to the individual learner, but also to the procedures in which they are presented. These factors make task grading difficult and therefore the sequencing of such tasks with the syllabus problematic. This can be seen as a weakness within the task-based syllabus that warrants further research.

\subsection{Implementation: Fluency at the Expense of Accuracy}

With its focus on meaning rather than form there is a danger that TBS promotes learner fluency at the expense of accuracy. Firstly, Skehan (1996) argues that learners possess a limited processing capacity "such that trade-offs between fluency, accuracy and complexity are likely to occur" (cited in Ellis 2000: 203). If students are focused solely on a meaningful exchange, they may rely heavily on communication strategies, at the expense of complexity or accuracy, to maintain the fluidity of an interaction (Skehan 1996: 21). Furthermore, even if 
students do switch their attention to form during task work, the code is still seen as peripheral to the focus on meaning (Flowerdew 2005: 136), putting fluency once again ahead of accuracy, which can prevent the development of interlanguage.

\subsection{Implementation: Fossilization}

TBS is based on theories of learning that stress the importance of interaction as a means to push student interlanguage systems forward and promote acquisition (see 3.2.2). However, this realization of TBS also runs the risk of creating conditions for fossilization to occur. Rich, comprehensible input is a key factor in the process of L2 acquisition. However, there is little guarantee that learner-learner interaction can provide this type of input to develop the interlanguage systems of the learner. Furthermore, the impoverished interactions (such as classroom pidgins or minimalization) that often result from pair and group work in the classroom carries with it the danger of fossilization. As Prabhu (1987) explains, the Bangalore Project did not use group work in the classroom because "learner-learner interaction [does] not promote development of interlanguage and may lead to fossilization" (cited in Robinson 2011: 10). Furthermore, in addition to impoverished communication as classified above, there is the risk that learners will rely on lexicalized communication when faced with excessively difficult tasks. The pressure of time and the need to get meanings across "places a premium on communication strategies linked to lexicalized communication" (Skehan 1996: 22). Skehan further notes, "Such a reliance carries the danger of fossilization and may produce only routine solutions to communication problems rather than tailor-made solutions" (1996: 23) thus rendering TBS as a means to acquisition ineffectual.

\section{Best Situations}

Based on the strengths and weaknesses identified in sections 4 and 5, it is this author's opinion that task-based syllabuses are best suited to smaller class sizes in the following type of language learning contexts:

\subsection{English for Specific Purposes}

TBS is particularly suited for English for Specific Purposes classes because of its use of needs analysis. The task-based syllabus takes the needs analysis as its point of departure in the syllabus design. As Willis \& Willis state, tasks that comprise the syllabus are determined by a needs analysis, which identifies the purpose and manner in which they will use the L2 (2007: 180). This practice is particularly useful for students in an ESP course as they have very specific and identifiable needs (Richards 2001). Thus, tasks provide these learners with a form of rehearsal for the real-world objectives they will need to accomplish with the language outside of the classroom.

\subsection{Adult Learners}

TBS is also ideal for adult learners because they have fully developed cognitive abilities. It is seen throughout the literature that tasks rely heavily on cognitive processing for both task completion and L2 acquisition (see 3.2, 3.3 and 4.1). Fully developed cognitive abilities in adults make task work more effective for language learning and acquisition as they are more 
capable of processing complex language and focusing on meaning as well as engaging in analyzing, deducting and abstracting processes (Brown 2007). In addition to this, adult learners have a greater "capacity to take initiatives and responsibility for their language learning" (Bruton 2002: 287), capacities that are ideally suited to the TBS.

\subsection{EFL Contexts}

Finally, this author would argue that TBS is especially ideal in EFL contexts where there is minimal opportunity for L2 language use outside the classroom. Within this learning context, many students have no immediate need to use the L2 and therefore do not have a sense of purpose for learning the L2 (Sheen 1994: 144). The task-based syllabus gives learners a purpose for language learning by providing them with opportunities to convey meaning and achieve tangible outcomes in the L2. This not only instills a sense of accomplishment in learners, which aids in increasing their motivation, but also demonstrates to them that they are able to use the language in a meaningful and productive way. It shows them the purpose of language learning.

\section{Arguments for the Task-Based Syllabus}

Many of the reasons for choosing TBS reside in its strengths (see section 4). In addition, this section outlines what the author believes are further arguments in favor of selecting TBS.

\subsection{Flexible Framework}

TBS offers a flexible framework for educators to promote L2 language learning. The tasks that make up a TBS allow for both a focus on form and the integration of that form into meaning. While Long's theory of negotiation (see section 3.3) holds that grammar and vocabulary can be acquired while working on tasks, there is also "credible evidence of distinct patterns of language on different task types" (Bygate 1999: 39), allowing us through task selection to give rise to the forms that learners might work on. Task recycling and the varying task conditions of the tasks themselves are further ways that allow us as educators to influence factors pertaining to the integration between form and fluency. Therefore, TBS is an important factor in providing a flexible framework for L2 acquisition.

\subsection{Communicative Competence}

Another argument in favor of TBS is that it emphasizes communicative competence. Meaningful communication is one of the primary goals in language learning and TBS reflects this by using meaning as its point of departure. Through authentic language exchange created by the task, students are given opportunities to develop their "ability to use the target language in real communication" (Van den Branden 2006: 2) and cultivate both social and non-verbal aspects involved in communication.

\subsection{Learner Individuality}

A final argument in favor of TBS is that it recognizes the individuality of the learner in two distinct ways. Firstly, it uses needs analysis as a starting point for syllabus design. This needs analysis "yields a list of the target tasks" (Nunan 2001: 1) that are specific to the individual 
learner which will then help to form the pedagogic tasks that will make up the syllabus. In this way the real world needs of the learner will be linked to the educational activity within the classroom.

Secondly, TBS allows for individual language development (Long and Robinson 1998 cited in Skehan 2002). Individual learners recognize their weaknesses in their language abilities through engaging in meaning negotiation and it is this that leads them to focus their attention on their personal language systems. SLA research has demonstrated that language learners do not all have the same point of departure or develop at the same rate. This highlights the importance of a language focus in the task-based syllabuses because it is learner initiated and learner controlled. As previously noted by Willis (see 4.4), each learner is in charge of deciding on what language items to focus on, when and why (Dave Willis 2007: 2).

\section{Conclusion}

After closely analyzing TBS, it is clear that TBS is informed by a theory of language that necessitates meaning and that theories of learning are at the heart of how best language is acquired. However, at the stage of design TBS suffers from two weaknesses, that of selection of tasks for General English courses and the grading and sequencing of tasks. In addition to this, at the implementation level there is the risk in some situations of fluency developing at the expense of accuracy and the occurrence of fossilization. Understanding these strengths and weaknesses helps us to understand situations that TBS is best suited for such as ESP, Adult Learner and EFL contexts. -

In the end, I believe that TBS is the most suitable syllabus for providing a flexible framework for L2 acquisition to take place. It recognizes that not all learners learn in the same way or at the same time, thus it is the closest thing to providing individually tailored learning and the most efficient for delivering communicative competence, which I believe is the overall goal in language teaching.

\section{Acknowledgement}

This work was supported by Hankuk University of Foreign Studies Research Fund 2014.

\section{Author Information}

Simon James Nicholson has been teaching EFL for nearly 13 years. He has lived and worked in India for five years and currently lives and works in South Korea. He is a professor at the Hankuk University of Foreign Studies in South Korea where he teaches Practical English courses. The author may be contacted at: Hankuk University of Foreign Studies, Foreign Languages Education Center, 89 Wangsan-ri, Moheyon-myeon, Cheoin-gu, Yongin-si, Gyeonggi-do, Korea 449-791. E-mail: simonjamesnicholson@gmail.com 


\section{References}

Beretta, A. (1989). 'Attention to Form or Meaning? Error Treatment in the Bangalore Project'. TESOL Quarterly, 23/2, 283-303.

Brown, H.D. (2007). Principles of Language Learning and Teaching. 5th ed. New York: Pearson Education.

Bruton, A.B. (2002). 'From tasking purposes to purposing tasks'. ELT Journal, 56/3, 280-288.

Butler, Y.G. (2011). The implementation of communicative and Task-Based Language Teaching in the Asia-Pacific Region. Annual Review of Applied Linguistics, 31, 36-57.

Bygate, M. (1999). 'Task as context for the framing, reframing and unframing of language'. System, 27 33/48, 33-48.

Duran, G., \& Ramaut, G. (2006). 'Tasks for absolute beginners and beyond: developing and sequencing tasks at basic proficiency levels' in Van den Branden, K. (ed), Task-Based Language Education: from theory to practice. Cambridge: Cambridge University Press, 47-75.

Edwards, C., \& Willis, J. (2005). Teachers Exploring Tasks in English Language Teaching. Cambridge: New York: Palgrave Macmillan.

Ellis, R. (1993). 'The Structural Syllabus and Second Language Acquisition'. TESOL Quarterly, 27/1, 91-113.

Ellis, R. (2000). Task-based research and language pedagogy. Language Teaching Research, 4/3, 193-220.

Ellis, R. (2003). 'Designing a Task-Based Syllabus'. RELC Journal, 34/64, 64-81.

Ellis, R. (2009). 'Task-based language teaching: sorting out the misunderstandings'. International Journal of Applied Linguistics, 19/3, 221-246.

Flowerdew, L. (2005). 'Integrating traditional and critical approaches to syllabus design: the 'what', the 'how' and the 'why?'. Journal of English for Academic Purposes, 4, 135-147.

Gass, S. (1997). Input, interaction and the second language learner. Mahwah, NJ: Lawrence Erlbaum.

Lewis, M. (2002). 'Implications of a lexical view of language' in Willis, J. and Willis, D. (1996a). (eds.). Challenge and Change in Language Teaching. Oxford: Heinemann, 10-16.

Littlewood, W. (2004). 'The task-based approach: some questions and suggestions'. ELT Journal, 58/4, 319-326.

Lightbrown, P.M. (1984). 'Input and Acquisition in Second Language Classrooms'. TESL Canada Journal, 1/2, 55-68. 
Lightbrown, P.M \& Spada, N. (2006). How Languages are Learned. Oxford: Oxford University Press.

Long M.H. \& Crookes, G. (1992). 'Three Approaches to Task-Based Syllabus Design'. TESOL Quarterly, 26/1, 27-56.

Long, M.H. (1985). 'Input and second language acquisition theory' in Gass, Susan M. and Carolyn Madden. (1985). (eds.). Input in second language acquisition. Cambridge, MA: Newbury House Publishers.

Long, M.H. (1996). 'The Role of the Linguistic Environment in Second Language Acquisition' in W. Ritchie \& T. Bhatia (eds.), Handbook of Second Language Acquisition, 413-68. San Diego: Academic Press.

McGrath, I. (2002). Materials Evaluation and Design for Language Teaching. Edinburgh: Edinburgh University Press.

Nunan, D. (1987). 'Communicative language teaching: Making it work'. ELT Journal, 41/2, 136-145.

Nunan, D. (1991). Communicative Tasks and the Language Curriculum. TESOL Quarterly, 25/2, 279-295.

Nunan, D. (1999). Second Language Teaching \& Learning. Heinle \& Heinle Publishers.

Nunan, D. (2001). Aspects of Task-Based Syllabus Design. http://www3.telus.net/linguisticissues/syllabusdesign.html, Date of access: 25/11/2004.

Pica, T. (1994). 'Research on Negotiation: What does it Reveal about Second Language Learning Conditions, Processes and Outcomes?' Language Learning, 44, 493-527.

Pica, T. (1996). 'Second language learning through interaction: multiple perspectives'. Working Papers in Educational Linguistics, 12, 1-22.

Rahimpour, M. (2010). 'Current trends on syllabus design in foreign language instruction'. Social and Behavioral Sciences, 2, 1660-1664.

Richards, J.C. (2001). Curriculum Development in Language Teaching, 7th ed. Cambridge University Press.

Richards, J.C. \& Rodgers T.S. (2001). Approaches and Methods in Language Teaching, $2^{\text {nd }}$ ed. Cambridge University Press.

Richards, J.C. (2006). Communicative Language Teaching Today. Cambridge University Press.

Robinson, P. (2001). Task Complexity, Task Difficulty, and Task Production: Exploring Interactions in a Componential Framework. Applied Linguistics, 22/1, 27-57.

Robinson, P. (2011). Task-Based Language Learning: A review of Issues. Language Learning, 61/1, 1-36. 
Sheen, R. (1994). A Critical Analysis of the Advocacy of the Task-Based Syllabus. TESOL Quarterly, 28/1, 127-151.

Skehan, P. (1996). 'Second language acquisition research and task-based instruction' in Willis, J. and Willis, D. (1996a). (eds), Challenge and Change in Language Teaching. Oxford: Heinemann, 17-30.

Skehan, P. and Foster, P. (1999). 'The influence of source of planning and focus of planning on task-based performance'. Language Teaching Research, 3/3, 215-247.

Skehan, P. (2002). A non-marginal role for tasks. ELT Journal, 56/3, 289-295.

Skehan, P. (2003). Task-based instruction. Language Teaching, 36, 1-14.

Valdman, A. (2006). Communicative Use of Language and Syllabus Design. Foreign Language Annals, 11/5, 567-580.

Van den Branden, K. (2006). 'Introduction: task-based language teaching in a nutshell' in Van den Branden, K. (ed), Task-Based Language Education: from theory to practice. Cambridge: Cambridge University Press, 1-16.

Van Avarmaet, P. \& Gysen, S. (2006). 'From needs to tasks: language learning needs in a task-based approach' in Van den Branden, K. (ed), Task-Based Language Education: from theory to practice. Cambridge: Cambridge University Press, 17-46.

Van den Branden, K. (2006). Task-Based Language Education: from theory to practice. Cambridge: Cambridge University Press.

White, R.V. ( 1988). The ELT Curriculum. Oxford: Blackwell.

Willis, D. (1996a). 'Accuracy, fluency and conformity' in Willis, J. and Willis, D. (1996a). (eds). Challenge and Change in Language Teaching. Oxford: Heinemann, 44-51.

Willis, J. (1996a). 'A flexible framework for task-based learning' in Willis, J. and Willis, D. (1996a). (eds), Challenge and Change in Language Teaching. Oxford: Heinemann, 52-62.

Willis, J. \& Willis, D. (1996a). (eds). Challenge and Change in Language Teaching. Oxford: Heinemann.

Willis, J. and Willis, D. (1996a). 'Conscious-raising activities in the language classroom' in Willis, J. and Willis, D. (1996a). (eds), Challenge and Change in Language Teaching. Oxford: Heinemann, 63-76.

Willis, J. (1996b). A Framework for Task-based Learning. Harlow: Longman.

Willis, J. and Willis, D. (2007). Doing Task-Based Teaching. Oxford: Oxford University Press.

Willis, J. and Willis, D. (2007). 'Designing a Task-Based Syllabus' in Willis, J. and Willis, D. (2007). Doing Task-Based Teaching. Oxford: Oxford University Press. 
Willis, D. (2007). Accuracy, Fluency and Autonomous Learning: A Three Way Distinction. www.willis-elt.co.uk/ Date of access: March 212012.

\section{Copyright Disclaimer}

Copyright reserved by the author(s)..

This article is an open-access article distributed under the terms and conditions of the Creative Commons Attribution license (http://creativecommons.org/licenses/by/3.0/).. 